\title{
MODEL PENYELESAIAN ALTERNATIF PERKARA PIDANA DALAM HUKUM ISLAM DAN RELEVANSINYA DENGAN PEMBAHARUAN HUKUM PIDANA INDONESIA
}

\author{
Hambali Yusuf, Saifullah Basri \\ Fakultas Hukum Universitas Muhammadiyah Palembang \\ Jalan A.Yani 13, Ulu, Palembang \\ E-mail : hambaliyusuf@ymail.com
}

\begin{abstract}
Many criminal cases that are not resolved either at the level of appeal or cassation level is an indication that there are problems in law enforcement. Islamic Criminal Justice provides much alternative settlement of criminal cases by maintaining a balance of the interests of the victim, the community, the State and the offender. This research aims to analyze the model, explain the alternative settlement of criminal cases in the Islamic law; how setting the model settlement of criminal cases in the Islamic law can be used as a model settlement of criminal cases in the criminal law of Indonesia, to find a model settlement of criminal cases in the Islamic law of relevance to criminal law updates Indonesia. This research got that setting jarimah qishas-diyat placed as a kind of private law as rights adami. Setting model jarimahdiyat can allow made a model in settlement of a criminal offence in the criminal law of Indonesia in line with developments in the modern criminal law sanctions governing sanctions fines or compensation for victims. Setting model jarimah-diyat can allow made a model in settlement of a criminal offence in the criminal law of Indonesia in line with developments in the modern criminal law sanctions governing sanctions fines or compensation for victims.
\end{abstract}

Keywords: Alternative Settlement Model, Criminal Case, Islamic Law, Renewal of Criminal Law in Indonesia.

\begin{abstract}
Abstrak
Banyak perkara pidana yang tidak tereselesaikan baik pada tingkat banding, maupun tingkat kasasi adalah indikasi bahwa ada persoalan dalam penegakan hukum. Peradilan pidana Islam memberikan solusi banyak alternatif penyelesaian perkara pidana dengan menjaga keseimbangan kepentingan korban, masyarakat, negara dan pelaku. Penelitian bertujuan untuk menganalisis, menjelaskan model penyelesaian alternatif perkara pidana dalam hukum Islam; bagaimana pengaturan model penyelesaian perkara pidana dalam hukum Islam dapat dijadikan model penyelesaian perkara pidana dalam hukum pidana Indonesia, untuk menemukan model penyelesaian perkara pidana dalam hukum Islam relevansinya dengan pembaharuan hukum pidana Indonesia. Hasil penelitian ini menunjukkan bahwa pengaturan jarimah qishas-diyat ditempatkan sebagai jenis hukum privat sebagai hak adami. Pengaturan model jarimah-diyat dapat memungkinkan dijadikan model dalam penyelesaian tindak pidana dalam hukum pidana Indonesia sejalan dengan perkembangan sanksi dalam hukum pidana modern yang mengatur sanksi denda atau ganti rugi bagi korban.
\end{abstract}

Kata Kunci: Model Penyelesaian Alternatif, Perkara Pidana, Hukum Islam, Pembaharuan Hukum Pidana Indonesia. 


\section{A. PENDAHULUAN}

Banyak perkara pidana yang tidak tereselesaikan baik pada tingkat banding, maupun tingkat kasasi dapat menjadi indikasi bahwa ada persoalan dalam penegakan hukum yang harus dicarikan jalan keluarnya untuk mencapai kepastian hukum sebagai bentuk rasa keadilanyang diinginkan bagi setiap orang. Menurut data laporan tahunan Mahkamah Agung tahun 2013 sisa perkara pidana pada tingkat kasasi 6.415 perkara. ${ }^{1}$ Ini dapat diartikan bahwa pencari keadilan tidak puas dengan proses peradilan yang dilaksanakan pada tingkat pertama dan banding.

Model penyelesaian tindak pidana yang dilaksanakan oleh peradilan pidana Indonesia yaitu "konsep pemidanaan individual/personal." ${ }^{\text {k }}$ konsep ini menekankan kepada perbaikan pelaku (dader), sementara korban dan masyarakat diabaikan. Pembaharuan hukum pidana nasional harus bersumber pada falsafah kehidupan bangsa Indonesia sumber dari segala sumber hukum yaitu Pancasila. Diantara sumber hukum itu adalah hukum Islam dan hukum adat, maka peradilan pidana Islam memberikan solusi yang dapat digunakan sebagai alternatif penyelesaian perkara pidana dengan maksud untuk menjaga keseimbangan kepentingan rasa keadilan dan capaian kepastian hukum bagi korban, masyarakat, negara dan pelaku.

Hukum Islam merupakan salah satu bahan hukum bagi pembangunan hukum dan banyak telah menjadi hukum positif Indonesia. Penulis-penulis Belanda seperti Prof. Mr. Lodewijk Willem Christian van de Berg (1845 - 1927) menyatakan bahwa hukum Islam itu berlaku di Indonesia untuk orang Islam ${ }^{3}$. Pendiriannya ini kemudian terkenal dengan teori Receptio in Complexu.Hukum Islam direpsi menjadi hukum setempat (hukum Nasional).

Hukum pidana Islam dikenal tiga macam jarimah (tindak pidana) yaitu: (1) jarimahhudud, (2) jarimah Qishas-diyat, (3) jarimah ta'zir. Ketiga jarimah ini mempunyai kelenturan dalam penerapannya yang dapat dijadikan sebagai bahan pembahruan hukum pidana nasional. $^{4}$

Dilihat dari sisi kebijakan hukum pidana model penyelesaian yang ditawarkan hukum pidana Islam menarik untuk dikaji untuk dijadikan kebijakan legislatif dalam menyusun Rencana hukum nasional Indonesia yang akan datang (sebagai ius constituendum).

\section{B. RUMUSAN MASALAH}

Dari pendahuluan di atas maka penulis merumuskan persoalan dalam tulisan ini adalah; Bagaimana bila Model peneyelesaian Pidana Hukum Islam Jarimah Qishas diyat yang memiliki unsure pemaaf sebagaimana model penyelesaian tindak pidana Restorative Justice dapat digunakan dalam proses pembaharuan Hukum Pidana Nasional KUHP.

\section{METODE PENELITIAN}

Jenis penelitian ini adalah penelitian hukum normatif, yaitu penelitin terhadap azas-azas

\footnotetext{
${ }^{1}$.Rahmat Fiansyah, laporan tahunan Mahkama Agung tahun 2013, Kompaskom, 26 Februari 2014. https://www.mahkamahagung.go.id/images/LTMARI-2013.pdf

${ }^{2}$ Barda Nawai Arief, Bunga Rampai Kebijakan Hukum Pidana, Citra Aditya Bakti, Bandung. 1996,hlm. 49

${ }^{3}$ Sayuti Thalib, 1985, Receptio A Contrario (Hubungan Hukum adat dengan Hukum Islam), Bina Aksara, Jakarta. Hlm.4-5.

${ }^{4}$ Ridwan, Limitasi Hukum Pidana Islam, Wali Songo Press, 2008, Semarang, hlm.16
} 
hukum, penelitian sistematika hukum, penelitian taraf sinkronisasi hukum, penelitian sejarah hukum, dan penelitian perbandingan hukum. ${ }^{5}$ Penelitian ini meneliti azas-azas hukum pidana dan hukum pidana islam.

Data dari studi literature dan perundang-undangan ditelusuri, dianalisis yang kemudian ditarik azas hukum apa yang ada dalam undang-undang tersebut. Sebagai contoh azas peradilan cepat dan biaya ringan dalam hukum acara pidana, azas keadilan, dan lain-lainnya. Dalam KUHAP terdapat sejumlah pasal yang merupakan kaedah hukum, ditelusuri untuk menemukan azas hukumnya. Selanjutnya dilakukan penelusuran hukum Islam untuk menemukan azas sebagai model penyelesaian kasus tindak pidana .

\section{PEMBAHASAN}

\section{Model Penyelesaian Alternatif Perkara Pidana Menurut Hukum Islam yang Dapat Dijadikan Model Penyelesaian Kasus Tindak Pidana Di Indonesia}

Dimaksud model penyelesaian disini adalah bagaimana kebijakan hukum pidana Islam dalam menanggulangi dan mencegah kejahatan dapat dijadikan suatu model kebijakan kriminal dalam hukum pidana Indonesia. Pengertian kebijakan pidana dari perspektif Pidana umum adalah:

a. Kebijakan pidana (criminal policy) adalah suatu Usaha untuk mewujudkan peraturan-peraturan yang baik sesuai dengan keadaan dan situasi pada suatu saat.

b. Kebijakan dari negara melalui badan-badan yang berwenang untuk menetapkan peraturan-peraturan yang dikehendaki yang diperkirakan bisa digunakan untk mengekspresikan apa yang terkadunng dalam masyarakat dan apa yang dicitacitakan. $^{6}$

Penanggulangan dan pencegahan tindak pidana dengan menggunakan hukum pidana (panal aflication) dan dengan tidak menggunakan pidana (without panal) tetapi menggunakan sarana lain diluar hukum pidana. Yaitu melakukan pencegahan dengan melihat penyebab terjadinya kejatahan.Masalah-masalah social dan masalah kemanusiaan, ekonomi dan lain-lain dapat menyebabkan terjadinya kejahatan. Pengintegralan kedua pendekatan ini perlu dilakukan dalam rangka pencegahan dan penanggulan kejahatan.

Hukum pidana Islam (Fiqh Jinayah) mengenal 3 (tiga) model dalam menyelesaikan tindak pidana (jarimah) qishas-diyat yaitu tindak pidana (jarimah) pembunuhan biasa atau pembunuhan karena kelalaian, berikut 3 model tersebut:

a. Model penyelesaian qishas

b. Model penyelesaian maaf-diyat

c. Model maaf

Ketiga model ini diterapkan dalam praktik peradilan pidana Islam sampai saat ini dan dalam perkembangan sistem peradilan pidana modern saat ini dikenal dengan model

\footnotetext{
${ }^{5}$ Soerjono Soekanto, Pengantar Penelitian Hukum, UI Press,1986, Jakarta. hlm.51

${ }^{6}$ Barda Nawai Arief, op.cit Hlm 28
} 
penyelesaian restorative justice yaitu pola penyelesaian dengan pendekatan keadilan substantif dalam masyarakat, bukan pola penegakan hukum dengan pola keadilan undangundang atau keadilan formal.

a. Model pertama adalah penyelesain model qishas-diyat dapat ditelusuri dengan cara penyelesaian menggunakan litigasi dan non litigasi. Cara atau model penyelesaian dengan litigasi yaitu menerapkan qishas atau balasan setimpal jika pelaku tidak mendapat maaf dari korban, Pengadilan yang akan memutuskan untuk menyatakan bahwa pelaku jarimah dieksekusi qishas.

b. Model kedua adalah penyelesaian jarimah yaitu menerapkan cara non litigasi atau negosiasi dimana penyelesaian dilakukan dengan negosiasi damai antara korban dengan pelaku dengan cara bahwa pelaku jarimah diberi maaf oleh korban atau keluarga korban dengan cara membayar diyat atau kerugian jika cara ini disepakati maka pembayaran diyat dapat membebaskan pelaku jarimah dari hukuman qishas.

c. Model ketiga yaitu pola penyelesaian pemberian maaf dari korban atau keluarga korban tanpa membayar diyat ataupun denda tetapi hakim bisa menghukum pelaku jarimah diyat dengan ta'zir.

Menurut konsep pidana Islam pembunuhan sengaja atau pembunuhan- tidak sengaja tidak merusak tertiban umum, sebab masyarakat tidak merasakan akan akibat takut atau resah atau berpikiran akan menjadi korban berikutnya. Pelaku jarimah ini hanya menaruh niat jahat pada korban saja, maka atas dasar berpikir inilah maka sesungguhnya yang harus dilindungi itu adalah korban dan keluarga korban.

Sesungguhnya dalam konsep model penyelesaian jarimah qishsas-diyat ini terkadung nilai keluhuran akhlak dan kasih sayang, dimana dalam praktik peradilan Rasulullah selalu mengedapankan kasih sayang dengan moral dalam menyelesaikan jarimah qishas-diyat. Nabi mendorong supaya tidak menggunakan pembalasan naumn mengedepankan pemberian maaf: "sepengetahuan saya setiap ada perkara qishas dilaporkan kepada Rasulullah SAW, maka beliau selalu memerintahkan agar dimaafkan" (HR Annas bin Malik). Sehubungan dengan pemaafan para ulama sepakat tentang pemaafan qishas, bahkan lebih utama dari pada menuntutnya. Hal ini didasarkan pada firman Allah:

"Maka barang siapa mendapat pemaafan dari saudaranya, hendaklah ia mengikutinya dengan baik, dan membayar diyat (tebusan) dengan baik pula. Yang demikian itu keringanan dan rahmat dari Tuhanmu. Barang siapa melampau batas setelah itu, maka ia akan mendapat azab yang pedih" (QS. 2:178).

"Barangsiapa siapa melepaskan (hak qishas) nya, maka itu (menjadi) penebus dosa baginya...” (QS. 5:45).

Dari kedua firman Allah,Swt di atas jelaslah bahwa Hukum pidanaIslammengedapankan penyelesaian dengan mengedepankan pemaafan dari pada membalas. Inilah salah satu model 
penyelesaian yang solutif. Penyelesaian jarimah model ini sekaligus membantah dan meluruskan tentang Hukum pidana Islam atas pikiran pendapat masyarakat barat bahwa hukum pidana Islam bar-bar dengan hukuman qishas-nya sebagai pembalasan jiwa dibalas jiwa, melukai dibalas dilukai. Dikatakan ini tidak cocok dengan peradaban manusia modern.

\section{Pengaturan Model Penyelesaian alternative Perkara Pidana menurut Hukum Islam dapat dijadikan Model Penyelesaian Tindak Pidana di Indonesia}

Pengaturan Model penyelesaian jarimah qishsas-diyat secara legalistik dirumuskan dalam Kitab Suci AL-Quran dan Al-Hadist. Pengaturannya secara tegas dan termasuk ayat Qoth' $i$ dalam Al-Quran dan Al-Hadist sehingga tidak menimbulkan perbedaan dalam memahaminya.

Jarimah qishas-diyat diatur secara khusus dalam Al-Quran dan Al-Hadist yang terdiri dari jarimah pembunuhan sengaja,pembunuhan tidak sengaja dan penganiayaan semi sengaja dan tidak sengaja.

Formulasi hukuman jarimah qishas-diyatdalam hukum pidana Islam adalah unik. Tidak seperti hukum positif Barat yang menggolongkan kejahatan pembunuhan atau penganiayaan dalam aspek pidana murni, hukum islam menyertakan aspek perdatanya. Sebagaimana yang dikatakan Daud Ali "hukum Islam tidak membedakan (dengan tajam) antar hukum perdata dengan hukum publik. Ini disebabkan karena menurut sistem hukum Islam pada hukum perdata terdapat segi-segi publik dan pada hukum publik ada segi-segi perdatanya."7 Bahkan menurut Syahrur aspek ini yang lebih dominan meskipun tidak mengabaikan aspek pidananya. $^{8}$

Bila dalam perspektif hukum positif kejahatan tersebut menyangkut kepentingan publik, sehingga wewenang untuk menjatuhkan hukuman sepenuhnya ada di tangan negara, tanpa campur tangan korban sedikitpun untuk menghapus atau mengganti hukuman. Sementara dalam hukum pidana Islam pihak korban atau para walinya bisa memaafkan hukuman qishas untuk diganti dengan hukuman diyat yang diserahkan kepada mereka. Sebagaimana firman Allah dalm Surat Al-Isra':

“...dan barang siapa dibunuh secara zalim, maka sungguh kami telah memberi kekuasaan kepada walinya...”(QS. 17:33).

Menurut tafsir Kementerian Agama maksud kekuasaan disini ialah hak ahli waris yang terbunuh atau penguasa untuk menuntut qishas atau diyat.

Model penyelesaianp jarimah qishas-diyat dalam hukum pidana islamyang melibatkan korban tidak dirumuskan dalam ketentuan tertulis layaknya dalam system model penyelesaian kasus pidana indonesia yang menggunakan mekanisme sistem peradilan pidana yang menggunakan hukum formil, hukum materiil, dan hukum pelaksanaan. Dalam hukum Pidana Islam sepenuhnya diselesaikan diluar sistem peradilan pidana. Model penyelesaian jarimah qishsas diyata ini sesungguhnya diadopsi oleh hukum adat. Ketentuan penyelesaiannya

\footnotetext{
7. Mohammad Daud Ali, Asas-Asas Hukum Islam (hukum Islam II):Pengantar Ilmu Hukum dan Tata Hukum Islamdi Indonesia. CV Raja Wali, Jakarta. 1991, hlm.52

${ }^{8}$ Muhammad Syahrur, , Limitasi Hukum Pidana Islam, Wali Songo Press, 2008, Semarang. Hlm. 33
} 
dilakukan dalam majelis peradilan adat.

Model penyelesaian diluar peradilan pidana sesungguhnya sudah dimulai dengan gagasan restorative justice. Model penyelesaian ini menghendaki pelibatan korban, masyarakat dan pelaku dalam menyelesaikan tindak pidana. Kendati dalam pelaksanaanya masih terbatas pada tindak pidana pelanggaran yang diancam dengan pidana denda. Sebagaimana yang terdapat di dalam Pasal 82 KUHP telah adanya penyelesaian diluar pengadilan (afdoening buiten proces). Demikian juga model penyelesaian tindak pidana anak yang ditur dalam Undang-undang nomor 11 tahun 2012 adanya penyelesaian diversi dalam perkara anak. Anak yang berkonplik dengan hukum pidana yang diancam dengan pidana dibawah lima tahun harus dilakukan penyelesaian dengan diversi melibatkan korban, masyarakat dan pelaku penyelesaian tidak menggunakan hukum pidana. Model penyelesaian model hukum pidana qishas diyat sangat relevan dijadikan model penyelesaian tindak pidana yang hanya merugikan korban, dan tidak merugikan masyarakat dan negara untuk dimasukkan dalam rancangan perubahan KUHP Indonesia.

\section{Model Penyelesaian Alternatif Perkara Pidana Menurut Hukum Pidana Islam Relevansinya dengan Pembaharuan Hukum Pidana Indonesia.}

Model penyelesaian perkara pidana menurut hukum Islam sangat relevan dengan pembaharuan hukum pidana Indonesia. Terdapat beragam parameter yang bisa menjadi tolok ukur serta ukuran relevansi hukum Islam dalam rangka pembaharuan hukum pidana Nasional (KUHP).

Persepektif hukum Islam dalam konstitusi UUD 1945. Di bawah Bab Agama, dalam Pasal 29 ayat (1) UUD 1945 dinyatakan bahwa Negara (Republik Indonesia) berdasarkan atas Ketuhanan Yang Maha Esa. Menurut Hazairin dalam bukunya Demokrasi Pancasila yang dikutif oleh Daud Ali: (1) Dalam negara Republik Indonesia tidak boleh terjadi berlaku sesuatu yang bertentangan dengan kaidah-kaidah Islam bagi ummat Islam, atau yang bertentangan dengan kaidah-kaidah agama Nasrani bagi ummat Nasrani, atau yang bertentangan dengan kaidah-kaidah ummat Hindu-Bali bagi orang-orang Hindu-Bali, atau bertentangan dengan kaidah-kaidah kesusilaan bagi orang-orang Budha. Ini berarti bahwa di dalam Negara Republik Indonesia tidak boleh berlaku atau diberlakukan hukum yang bertentangan dengan normanorma (hukum) agama dan norma kesusilaan bangsa Indonesia; (2) Negara Republik Indonesia wajib menjalankan syari'at Islam bagi orang Islam, syari'at Nasrani bagi orang Nasrani, dan syari'at Hindu-Bali bagi orang Bali. ${ }^{9}$

Apa yang menjadi ukuran relevansi hukum pidana Islam khususnya jarimah qishsasdiyat dalam rangka pembaharuan hukum pidana nasional (KUHP)?. Menurut Mohammad Taufiq Makaro ada tiga ukurana yaitu (1) relevansi yuridis, (2) relevansi sosiologis, (3) relevansi filosofis, (4) harus dapat dipertanggung jawabkan secara ilmiah. ${ }^{10}$ Keempat ukuran ini dapat dijadikan kebijakan pidana khususnya masalah yang berhubungan dengan

\footnotetext{
${ }^{9}$ Daud Ali, op.cit, hlm.7

${ }^{10}$ Mohammad Taufik Makarao, Pembaharuan hukum Pidana Indonesia, Kreasi Wacana, 2005, Yogyakarta, hlm 9
} 
pengundangan perumusan oleh Lembaga Legislatif dan jadi pemikiran khusus bagi Lembaga Eksekutif untuk capaian rasa keadilan di dalam Masyarakat sesuai ruang kedekatan emosi yaitu keadilan masyarakat.

\section{E. PENUTUP}

\section{Kesimpulan}

Berdasarkan hail penelitian didapatkan kesimpulan bahwa :

a. Model penyelesaian alternatif perkara Pidana dalam perspektif Hukum Islam dapat dijadikan model penyelesaian tindak pidana di Indonesia adalah terhadap jarimah qishas-diyat korban mempunyai hak otonomi untuk memberi maaf dengan cara membayar denda kepada korban atau dapat memberikan maaf tanpa membayar denda apapun.

b. Pengaturan modelpenyelesaian perkara pidana menurut hukum Islam dapat dijadikan model penyelesaian tindak pidana di Indonesia: pengaturan jarimah qishas-diyat ditempatkan sebagai jenis hukum privat sebagai hak adami.

c. Model dalam hukum islam mempunyai relevansi yuridis, sosiologis, filosofis, dan dapat dipertanggung jawabkan secara ilmiah sebagai bahan hukum dalam pembaharuan hukum pidana Indonesia.

\section{Saran}

Dari hasil penelitian ini, hendaknya legislatif dan eksekutif dalam merumuskan tindak pidana pembunuhan biasa dan kejahatan terhadap badan serta kelalaian yang menyebabkan matinya orang lain memasukkan denda sebagai pidana pokok dan penyelesaian model diversi dengan merestorasi kepentingan korban dan masyarakat dalam KUHP Nasional.

\section{Daftar Pustaka}

Barda Nawai Arief, 1996. Bunga Rampai Kebijakan Hukum Pidana, Citra Aditya Bakti, Bandung.

Hanafi, A., 1970, Pengantar dan Sejarah Hukum Islam, Jakarta: Bulan Bintang

Mohammad Daud Ali, 1991. Asas-Asas Hukum Islam (hukum Islam II):Pengantar Ilmu Hukum dan Tata Hukum Islamdi Indonesia. CV Raja Wali, Jakarta.

Mohammad Daud Ali, 1996, Hukum Islam : Pengantar Ilmu Hukum dan Tata Hukum Islam di Indonesia, Jakarta: Raja Grafindo Persada

Mohammad Taufik Makarao, 2005. Pembaharuan Hukum Pidana Indonesia. Kreasi Wacana, Yogyakarta

Muhammad Syahrur, 2008. Limitasi Hukum Pidana Islam, Wali Songo Press, Semarang. Munawir Sjadzali. 1993. Islam dan Tata Negara (Ajaran, Sejarah Dan Pemikiran). Jakarta: UI Press.

Rahmat Fiansyah, Laporan Tahunan Mahkama Agung Tahun 2013, Kompaskom, 26 Februari Ridwan, 2008. Limitasi Hukum Pidana Islam, Wali Songo Press, Semarang. 
Sayuti Thalib, 1985, Receptio A Contrario (Hubungan Hukum Adat dengan Hukum Islam), Bina Aksara.

Shoayb Ahmed, 2005. The Development Of Islamic Jurisprudence (Fiqh) And Reason For Justice Dissagreement Among School of Law. Dissertation: University of South Africa.

Tim Penyusun, 2002, Islam Untuk Disiplin Ilmu Hukum, Jakarta: Ditjen Kelembagaan Agama Islam, Departemen Agama

Zainuddin Ali. 2006. Hukum Islam Pengantar Ilmu Hukum Islam di Indonesia. Jakarta: Sinar Grafika. 